Stratigraphic Nomenclature of the Thirtynine Mile Volcanic Field, Central Colorado

GEOIOGICAI. SIRVEY BULLETIN $1395-\mathrm{C}$ 



\section{Stratigraphic Nomenclature of the}

\section{Thirtynine Mile Volcanic Field, Central Colorado}

By RUDY C. EPIS and CHARLES E. CHAPIN

CONTRIBUTIONS TO STRATIGRA PHY

GEOLOGICAL SURVEY BULLETIN $1395-$ C

Descriptions of volcanic and nonvolcanic units showing their chemistry, age, and interrelationships

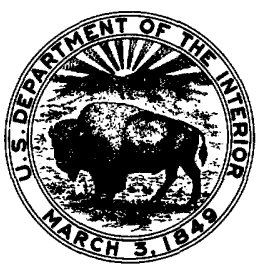




\section{UNITED STATES DEPARTMENT OF THE INTERIOR}

ROGERS C. B. MORTON, Secretary

\section{GEOLOGICAL SURVEY}

V. E. McKelvey, Director

Library of Congress catalog-card No. 74-600109

For sale by the Superintendent of Documents, U. S. Government Printing Office Washington, D. C. 20402 - Price 50 cents (paper cover) Stock Number 2401-02582 


\section{CONTENTS}

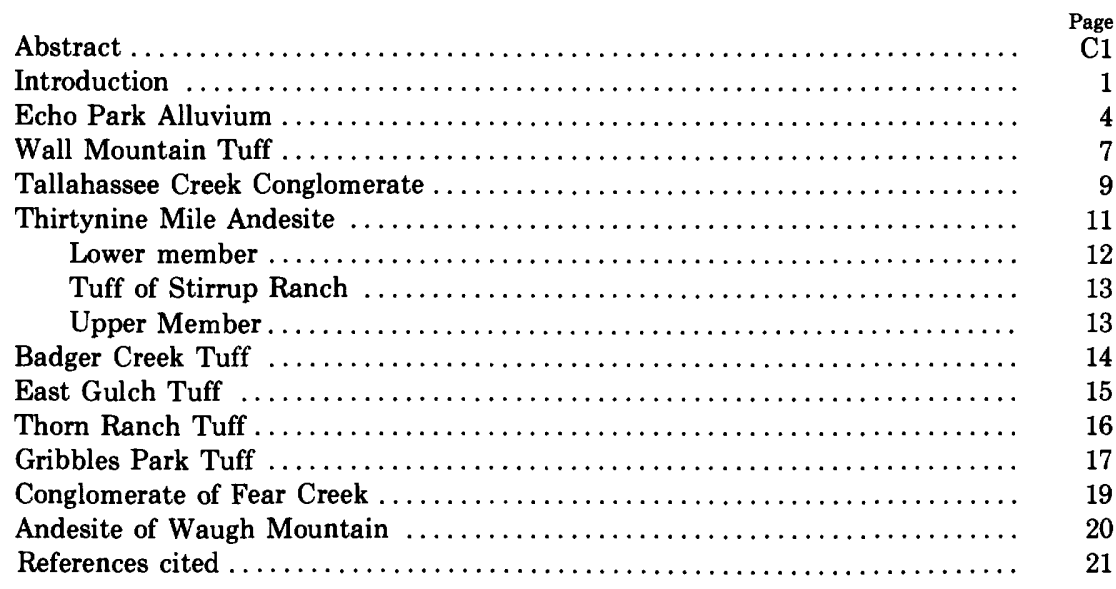

\section{ILLUSTRATIONS}

Figure 1. Map of the Thirtynine Mile volcanic field, showing its relations to other Cenozoic volcanic fields

2. Diagram showing generalized composite stratigraphy of the Thirtynine Mile volcanic field

\section{TABLE}

TABLE 1. Chemical composition of major volcanic units in the Thirtynine Mile volcanic field 



\title{
STRATIGRAPHIC NOMENCLATURE OF THE THIRTYNINE MILE VOLCANIC FIELD, CENTRAL COLORADO
}

\author{
By Rudy C. Epis ${ }^{1}$ and Charles E. Chapin ${ }^{2}$
}

\section{ABSTRACT}

The Thirtynine Mile volcanic field is a deeply dissected andesitic plateau built upon a late Eocene erosion surface of moderately low relief; numerous outliers are present in adjacent physiographic and tectonic settings in central Colorado. The volcanic field is characterized by andesitic rocks of local origin interspersed with rhyolitic to quartz latitic ash-flow tuffs erupted from sources outside the field. Potassium-argon ages on volcanic units range from 36 million years (early Oligocene) to 19 million years (early Miocene), but most of the volcanic pile was emplaced between 36 and 27 million years before the present. Sedimentary deposits of Tertiary age occur in a major graben beneath the field, in paleovalleys on the late Eocene erosion surface and, to a lesser extent, within the volcanic pile, in lake basins formed by blockaded drainages along the northern margin of the field, and in downfaulted basins which postdate the volcanism. Thirteen stratigraphic units are named and described in this report within a chronological framework established by field relationships and potassium-argon dating. Seven units are newly named herein, one unit previously named is adopted, and five units are given informal names. In ascending stratigraphic order, the units are Echo Park Alluvium, Wall Mountain Tuff (formerly named Agate Creek Tuff by De Voto, 1961), Tallahassee Creek Conglomerate (includes Alnwick Lake Beds and High Park Lake Beds of Cross (1894), which are here abandoned), Thirtynine Mile Andesite (formerly termed "Thirtynine Mile volcanic series" by Stark and others (1949) and includes informal members here called the lower member, the tuff of Stirrup Ranch, and the upper member), Badger Creek Tuff, East Gulch Tuff, Thorn Ranch Tuff, Gribbles Park Tuff, conglomerate of Fear Creek (informal name), and the andesite of Waugh Mountain (informal name).

\section{INTRODUCTION}

A sequence of lithologically distinct rock-stratigraphic units has been delineated in the Thirtynine Mile volcanic field and adjacent areas by geologic mapping during the past 13 years (fig. 1). Much of this work has been summarized in earlier reports (Chapin and Epis, 1964; Epis and Chapin, 1968) and will not be repeated here. Because geologic mapping was in progress and stratigraphic relations among some units were incompletely known, we used informal names in our earlier reports for

\footnotetext{
${ }^{1}$ Colorado School of Mines, Golden, Colo. 80401, and U.S. Geological Survey. Denver, Colo. 80225.

${ }^{2}$ New Mexico State Bureau of Mines and Mineral Resources, Socorro, N. Mex. 87801.
} 

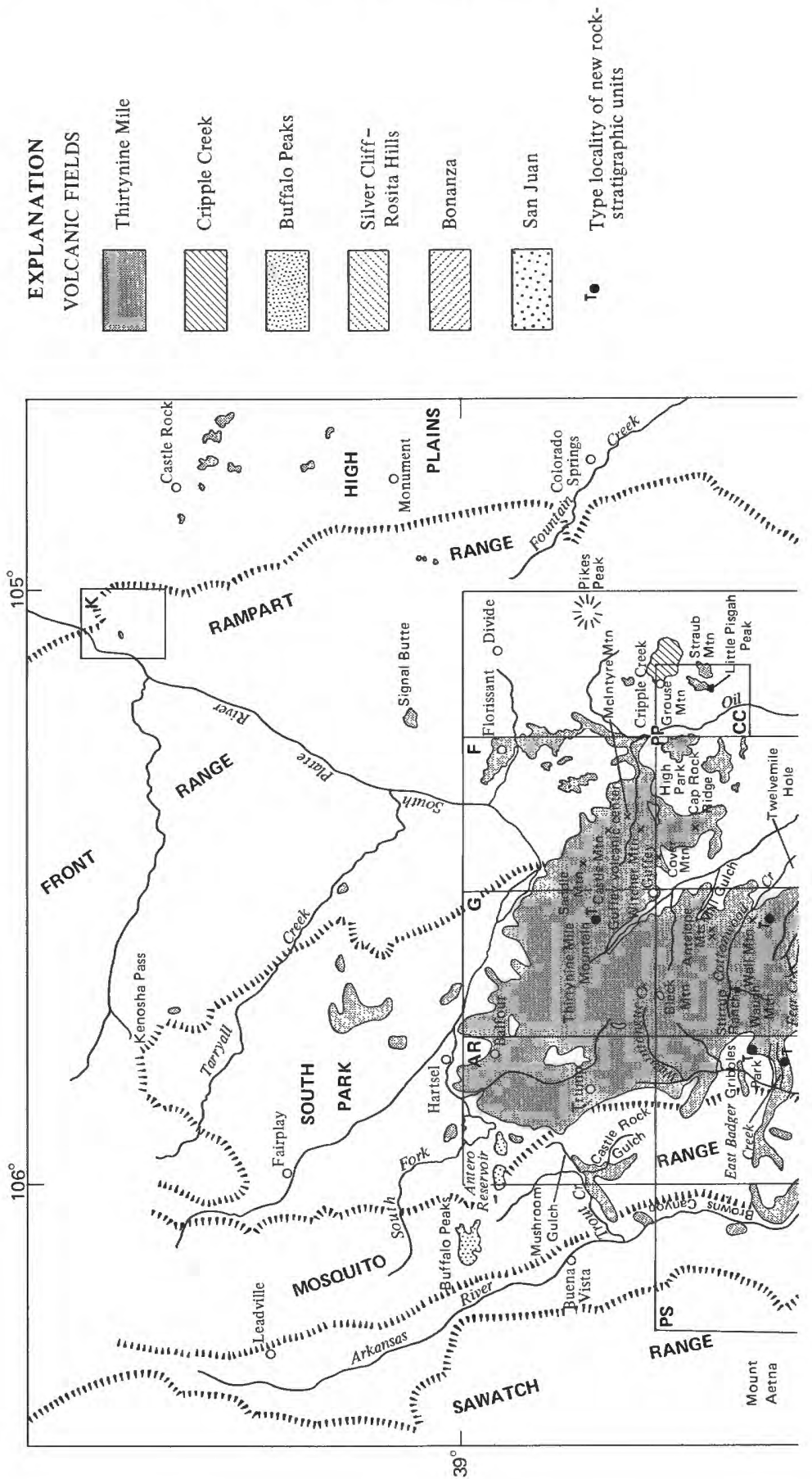


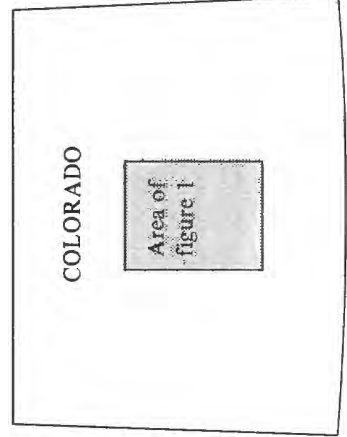

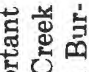
हैํㅐㅁ

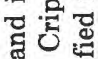

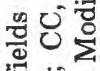

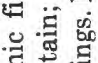

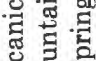
항 की 政 客 동 (a)
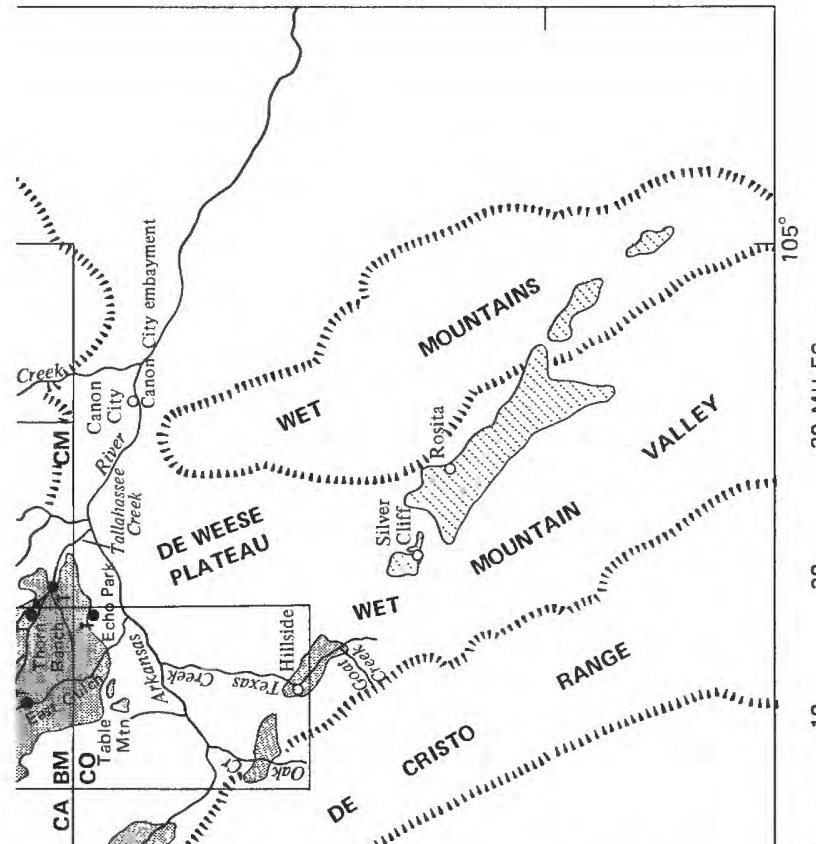

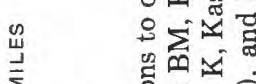

$\sum$ n

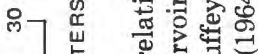
岁艾 \%

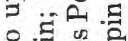

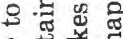

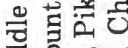
范嵒 氖毞焉

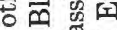

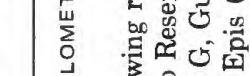
ㄱ- $\frac{\vec{x}}{0}$ 递芒 -

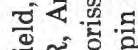

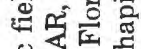
- - 욜

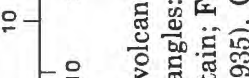
픙

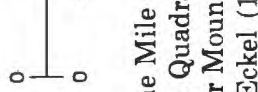

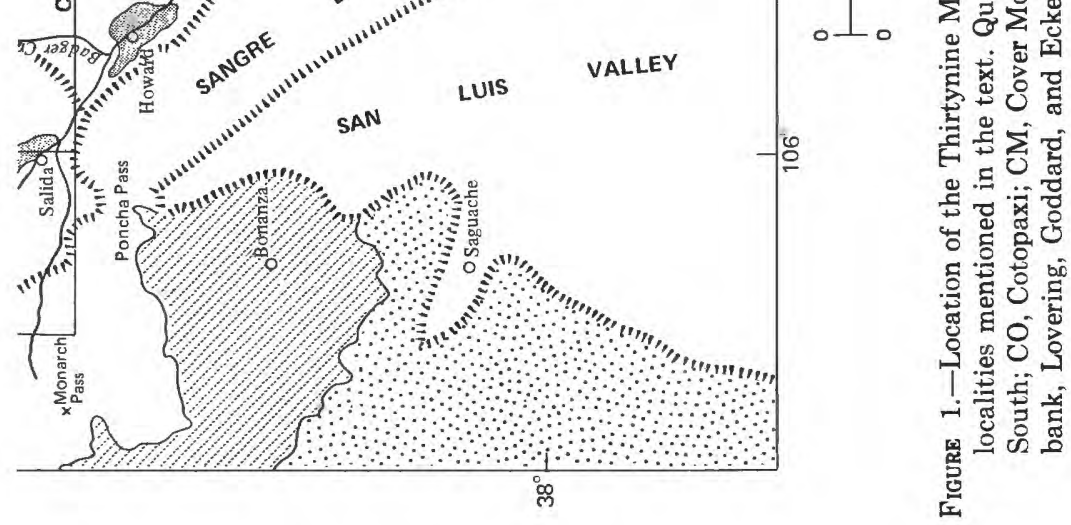


most of the Tertiary units. In this report, we assign formal names to seven units and abandon three; informal names are used for five units whose lateral extent is insufficient to justify a formal name or whose relationships are incompletely known. In ascending stratigraphic order, the units are the Echo Park Alluvium, Wall Mountain Tuff, Tallahassee Creek Conglomerate, Thirtynine Mile Andesite (including three informal members designated as the lower member, the tuff of Stirrup Ranch, and the upper member), Badger Creek Tuff, East Gulch Tuff, Thorn Ranch Tuff, Gribbles Park Tuff, conglomerate of Fear Creek (informal name), and andesite of Waugh Mountain (informal name). The interrelations of these units with formations whose names are already established in the literature are presented in figure 2 . The ages of epoch boundaries are those of Harland, Smith, and Wilcock (1964). Chemical analyses of some of the units named here are listed in table 1 .

The mapping on which this report is based was done by R. C. Epis and graduate students at the Colorado School of Mines, C. E. Chapin and graduate students at the New Mexico Institute of Mining and Technology, and G. R. Scott, R. B. Taylor, R. E. Van Alstine, and C. T. Wrucke of the U. S. Geological Survey. Graduate theses are listed in "References Cited"; they were completed by Buchanan (1967), Chapin (1965), De Voto (1961), DuHamel (1968), Graebner (1967), Lowell (1969), Lozano (1965), Morris (1969), Niesen (1969), Sawatzky (1967), Tobey (1969), Welsh (1969) and Wyckoff (1969). In 1966 several K-Ar (potassium-argon) ages were determined by Geochron Laboratories, Inc., under a research grant to C. E. Chapin, D. L. Sawatzky, and P. L. Siems. Recently, K-Ar ages were determined by J. D. Obradovich, of the U. S. Geological Survey, who kindly gave us permission to publish them in this report. We are indebted to all these individuals, both for important contributions and for helpful discussion. The responsibility for any errors in interpretation, however, rests solely with the authors.

\section{ECHO PARK ALLUVIUM}

Alluvium informally referred to (Epis and Chapin, 1968, p. 59) as the prevolcanic arkose is here named the Echo Park Alluvium for its excellent exposures at Echo Park on the north side of the Arkansas River in the central part of T. $18 \mathrm{~S}$., R. $73 \mathrm{~W}$. The type locality is designated along the part of Echo Canyon which is $1 \frac{3 / 4}{4}$ miles to $3 \frac{1}{2}$ miles northward from the Arkansas River (Cotopaxi quadrangle, fig. 1). Here the formation attains a thickness of about 900 feet in a graben formed in Precambrian rocks. The Echo Park is overlain by the Wall Mountain Tuff and the lower member of the Thirtynine Mile Andesite, at the type locality. Equally thick but not so well exposed outcrops of the Echo Park Alluvium occur along the valleys of North Tallahassee Creek, Cottonwood Creek, and Mill Gulch in the eastern half of the Black Mountain quadrangle. 
NOMENCLATURE, THIRTYNINE MILE VOLCANIC FIELD, COLO.

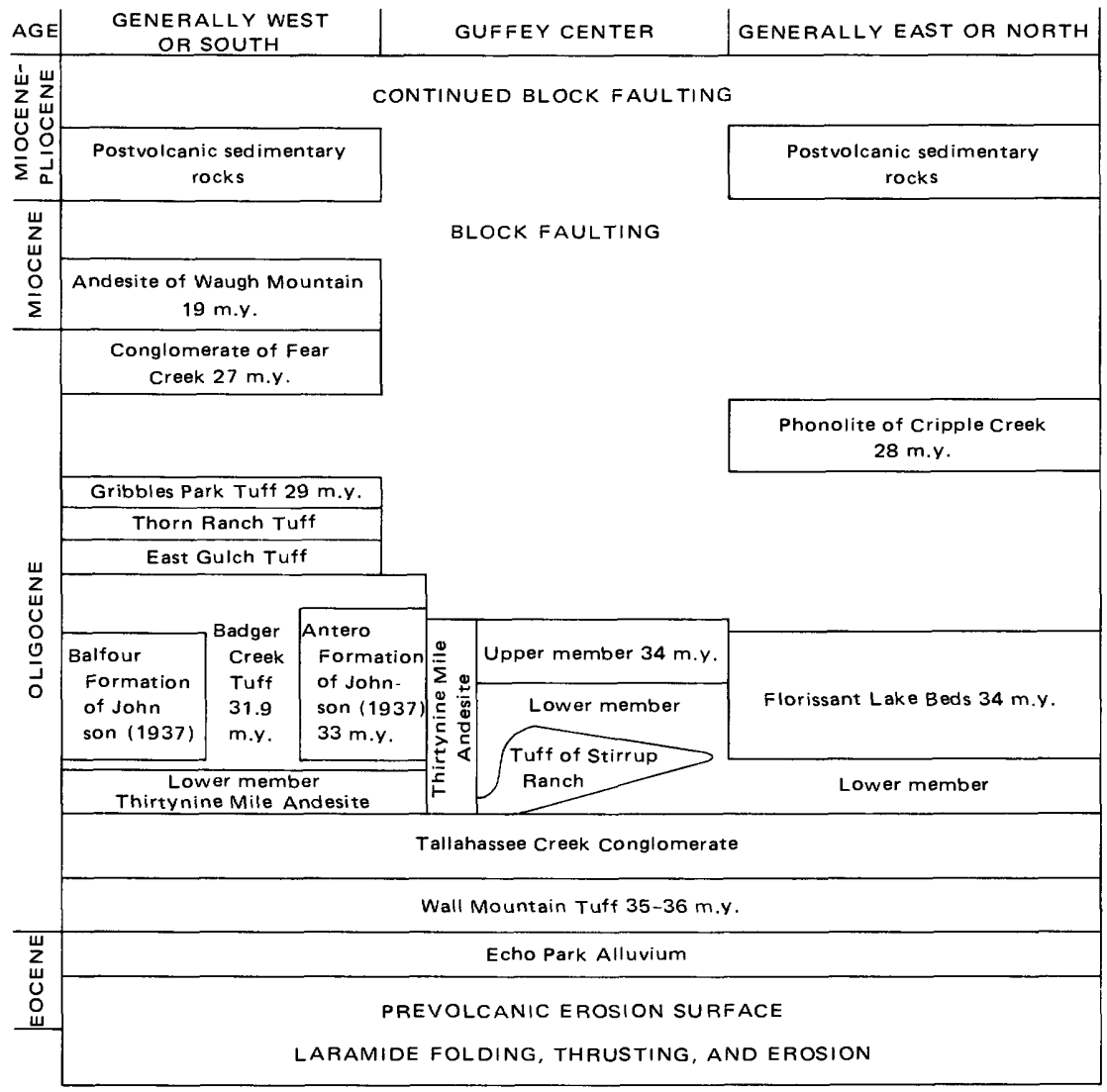

Figure 2.-Generalized composite stratigraphy of the Thirtynine Mile volcanic field. Epoch boundaries are those of Harland, Smith, and Wilcock (1964). Most intrusive and some extrusive rocks are not shown. (See Epis and Chapin, 1968, fig. 4.) Age of Badger Creek Tuff from C. W. Naeser (oral commun., 1973).

Drilling in these areas by Western Nuclear, Inc., in 1968 penetrated as much as 1,100 feet of Echo Park Alluvium and helped define a northnorthwest-trending graben, 2 to 4 miles wide, which extends more than 20 miles from the Arkansas River to the vicinity of Guffey. Abrupt changes in thickness within the graben seem to reflect a mosaic of fault blocks comprising the floor of the graben. Significant, but thinner, exposures of the formation are located at High Park in the northeastern part of the Cover Mountain quadrangle and at Mushroom Gulch in the east-central part of the Antero Reservior quadrangle.

The Echo Park Alluvium weathers reddish brown and is crudely stratified and only partially consolidated. It consists of poorly sorted material ranging from clay to boulder-size clasts 20 feet in diameter. The clasts are chiefly Precambrian plutonic igneous and metamorphic rocks of local derivation and are set in a matrix of micaceous sand, silt, 


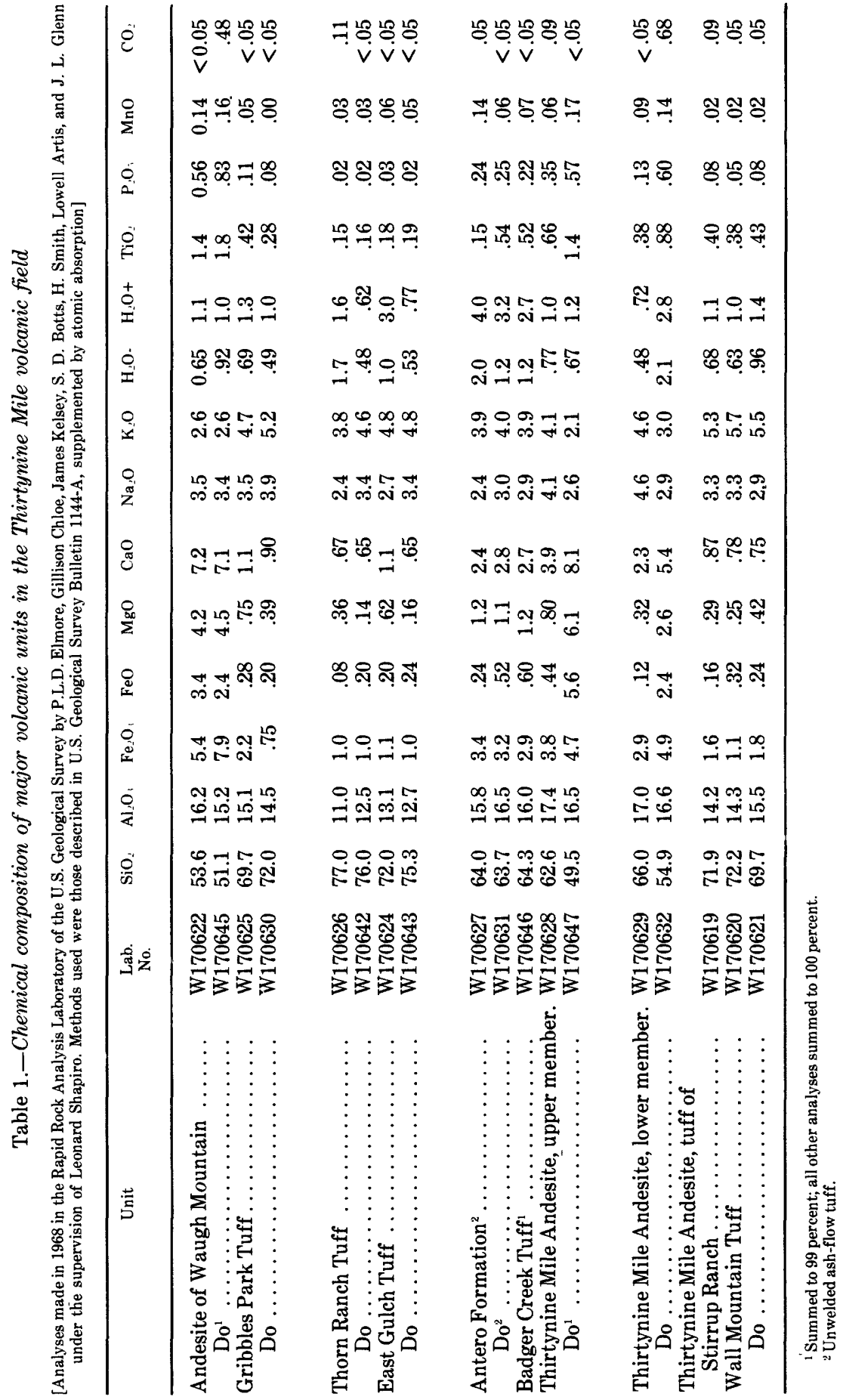


and clay. Most of the deposit represents alluvial sheet-wash accumulation, but arkosic fluvial sands and gravels are present locally, as at the Smaller uranium mine on North Tallahassee Creek and in Echo Park. About 70 percent of the footage drilled by Western Nuclear, Inc., was in red conglomeratic mudstone deposits; outcrops reveal a similar dominance of sheet-wash deposits.

The Echo Park overlies Precambrian crystalline bedrock as alluvial fills in paleovalleys or downfaulted basins. These depositional sites formed during the period of erosion that developed an extensive prevolcanic surface of low relief in late Eocene time (Epis and Chapin, 1968 , p. $56-60 ; 1973)$. The formation is overlain by either the Wall Mountain Tuff (35-36 m.y.), the Tallahassee Creek Conglomerate, or the lower member of the Thirtynine Mile Andesite. Accordingly, we assign the Echo Park Alluvium an Eocene age, and, on the bases of lithology, mode of deposition, and stratigraphic position, we suggest a correlation with the Huerfano Formation and Farisita Conglomerate (Johnson and Wood, 1956) to the south.

\section{WALL MOUNTAIN TUFF}

Chapin and Epis (1964) informally referred to rhyolitic ash-flow tuffs as ash flow 1 and ash flow 2 and commented that the rocks are megascopically very similar. Petrographic studies suggested the presence of additional ash-flow units and indicated that the unit was a multiple-flow simple-cooling unit containing at least four ash flows; accordingly, we referred to it in 1964 and 1968 as ash-flow 1 and mapped it as a single formation. De Voto (1964, p. 119) named outcrops of ash-flow tuff in southwestern South Park the Agate Creek Formation and incorrectly assigned it a stratigraphic position above the lower member of the Thirtynine Mile Andesite. We (Epis and Chapin, 1968, p. 67-68) referred to these outcrops as ash flow 4. Subsequent field and petrographic work has demonstrated that De Voto's Agate Creek Formation is older than the Thirtynine Mile Andesite and is part of the ash-flow 1 sheet. (See also De Voto, 1971, p. 29-35.) Because outcrops at De Voto's type locality of the Agate Creek are incomplete (only $11 \mathrm{ft}$ thick) and because important stratigraphic relations cannot be demonstrated, we here rename the Agate Creek Tuff of De Voto (1964) and ash flows 1, 2, and 4 of Chapin and Epis (1964) the Wall Mountain Tuff. The type locality of the Wall Mountain Tuff is along the south end of Wall Mountain in sec. 32, T. 16 S., R. 73 W., in the east-central part of the Black Mountain quadrangle (fig. 1). There, the formation dips about $6^{\circ} \mathrm{W}$. and forms prominent cliffs as much as 90 feet high. The formation rests on the Echo Park Alluvium and is overlain either by the Tallahassee Creek Conglomerate or by the lower member of the Thirtynine Mile Andesite. Elsewhere, the tuff was extensively eroded 
prior to the eruption of the Thirtynine Mile Andesite and generally occurs in isolated patches that are less than 50 feet thick. However, in paleovalleys incised into the prevolcanic surface, such as near Trout Creek and between Browns Canyon and Waugh Mountain, the tuff attains thicknesses of more than 500 feet.

The Wall Mountain Tuff generally weathers reddish brown to yellowish buff and tends to form clifflike outcrops; it exhibits moderate to dense welding and distinct eutaxitic structure imparted by flattened and stretched pumice lapilli and by partings that reflect laminar flowage. Locally, in the Antero Reservior quadrangle and in the northeastern part of the Poncha Springs quadrangle, a conspicuous black vitrophyre, as much as several tens of feet thick, is found above a light-colored thin nonwelded basal zone; vitrophyre is also locally present elsewhere in the volcanic field. More commonly, however, the tuff is completely devitrified and contains microcrystalline alkali feldspar and silica minerals of vapor-phase origin. Primary and secondary laminar-flowage structures are common (Lowell and Chapin, 1972).

Phenocrysts make up 18-33 percent of the rock. Fresh glassy clear sanidine and fresh to intensely argillized plagioclase (andesine) are the principal phenocrystic minerals. The sanidine to plagioclase ratio ranges from 0.9 to 4.4 and averages about 2.0. Sanidine (or anorthoclase) $2 \mathrm{~V}$ values range from $22^{\circ}$ to more than $50^{\circ}$ with median values for the four known ash flows of the Wall Mountain Tuff, in ascending order, of $30.5^{\circ}, 34^{\circ}, 38^{\circ}$, and $42^{\circ}$ (Chapin, 1965; Lowell, 1969). Quartz is absent as phenocrysts. Biotite and opaque oxides generally comprise about 6-9 percent of the rock; traces of pyroxene are present in most samples. Chemically, the Wall Mountain Tuff is a rhyolite (table 1). Accessory lithic fragments, consisting mainly of tan to light-red felsite, are abundant in the Browns Canyon area; they are generally present in outcrops along the west edge of the volcanic field but are sparse to absent elsewhere.

The Wall Mountain Tuff is the most widely distributed formation in the Thirtynine Mile volcanic field. Probable equivalents of the Wall Mountain occur at numerous localities throughout an area of about 3,500 square miles between Castle Rock (Izett and others, 1969) and the Kassler quadrangle (G. R. Scott, oral commun., 1972) on the northeast, South Park (Sawatsky, 1964, 1967) on the northwest, the northern Wet Mountain valley (Scott and Taylor, 1974) on the southeast, and northwest of Poncha Pass on the southwest. The Wall Mountain Tuff was referred to by earlier workers in South Park as a trachyte flow (Stark and others, 1949, p. 105-110) and in the Cripple Creek district as a rhyolite flow (Cross, 1894; Lindgren and Ransome, 1906, p. 100-101). An unnamed rhyolitic ash-flow tuff (Izett and others, 1969) beneath the Castle Rock Conglomerate in the Denver basin between Castle Rock and Monument is here assigned to the Wall Mountain Tuff because of 
similarity in age, lithology, $2 \mathrm{~V}$ values of sanidine, and chemical composition.

The tuff is one of the most important stratigraphic units in the Thirtynine Mile volcanic pile because it marks the onset of volcanism in earliest Oligocene time, preserves and dates a regional post-Laramide erosion surface, and serves as a datum for determining the location and magnitude of middle to late Cenozoic block faulting.

The source of the Wall Mountain Tuff is unknown. It must have been erupted from a volcanic center west of the upper Arkansas River valley between Salida and Buena Vista because it flowed into eastwarddraining paleovalleys in the southern Mosquito Range and eventually spread eastward over the region outlined above (Chapin and others, 1970). A deeply eroded cauldron complex in the Mount Aetna area north of Monarch Pass may be a possible source (Dings and Robinson, 1957; Lipman and others, 1969; P. J. Toulmin and G. A. Desborough, oral commun., 1973).

$\mathrm{K}$-Ar radiometric ages have been determined on samples from several localities of the tuff. Epis and Chapin (1968, p. 59) reported an age of $40.0 \pm 1.2 \mathrm{~m} . \mathrm{y}$., determined by Geochron Laboratories, Inc., from a sanidine separate. (We now consider this date too old, probably because of contamination by Precambrian microcline.) Izett, Scott, and Obradovich (1969, p. B13-B14) obtained a spurious age of $44.5 \pm 1.4$ m.y. from a sanidine separate contaminated by small amounts of microcline presumably from the Precambrian Pikes Peak Granite and an age, which they consider to be reliable, of $34.8 \pm 1.1 \mathrm{m.y}$., from biotite. Van Alstine (1969, p. 15) cited ages of $35.4 \pm 1.1$ and $37.3 \pm 1.9$ m.y. for sanidine and biotite, respectively. In $1973 \mathrm{~J}$. D. Obradovich determined ages for two additional samples of the Wall Mountain Tuff, as follows:

$\begin{array}{cccc}\text { Sample } & \text { Field No. } & \text { Mineral } & \text { Age (m.y.) } \\ & & & \\ 1 \ldots \ldots \ldots \ldots \ldots \ldots \ldots . . & 5-70-1 & \text { sanidine } & 34.7 \pm 0.7 \\ 2 \ldots \ldots \ldots \ldots \ldots \ldots \ldots & 68-0-39 & \text { sanidine } & 36.2 \pm 0.8 \\ & & \text { biotite } & 35.7 \pm 0.8\end{array}$

These samples are considered to be virtually uncontaminated; therefore, we assign an early Oligocene, or Chadron, age to the Wall Mountain Tuff. The unit has normal remanent magnetic polarity (Graebner, 1967; Graebner and Epis, 1968).

\section{TALLAHASSEE CREEK CONGLOMERATE}

Previously, we (Epis and Chapin, 1968) have called this deposit the lower volcanic conglomerate; we now name it the Tallahassee Creek Conglomerate for its excellent exposures, herein designated the type locality, at the junction of the three forks of Tallahassee Creek, in sec. 31, T. 17 S., R. 72 W., and sec. 36 , T. 17 S., R. 73 W., in the southwest corner of the Cover Mountain quadrangle and the southeast corner of the Black Mountain quadrangle (fig. 1). There, the conglomerate is as 
much as 350 feet thick and fills a meandering paleovalley about $1 / 2-2$ miles wide. The Tallahassee Creek Conglomerate rests on either the Wall Mountain Tuff, the Echo Park Alluvium, or Precambrian rocks and is overlain by either the lower member or, locally, the tuff of Stirrup Ranch, both of the Thirtynine Mile Andesite. Good exposures of the unit.occur along North Tallahassee Creek in secs. 9 and 10, T. $17 \mathrm{~S}$., R. $73 \mathrm{~W}$., and at the head of Twelvemile Hole, in secs. 29 and 32, T. 17 S., R. 72 W. Significant occurrences of conglomerate which we assign to this formation on the bases of similar lithology and stratigraphic position are found in the western and northern parts of the Antero Reservoir quadrangle, in the northwest corner of the Guffey quadrangle, on the lower slopes of Little Pisgah Peak, and on Grouse and Straub Mountains in the Cripple Creek South quadrangle. We also include in the Tallahassee Creek Conglomerate fairly extensive outcrops of the Alnwick Lake Beds and the High Park Lake Beds (Cross, 1894) in the southeast corner of the Florissant quadrangle and the northeast quarter of the Cover Mountain quadrangle. The names Alnwick and High Park are abandoned.

The Tallahassee Creek Conglomerate generally weathers gray or grayish pink in appearance. It is a poorly sorted, crudely stratified, partially consolidated accumulation of pebbles, cobbles, and boulders (as much as $5 \mathrm{ft}$ in diameter) in a tuffaceous to arkosic sandy and silty matrix. It fills paleovalleys cut into the Wall Mountain Tuff, the Echo Park Alluvium, and the Precambrian basement, and, locally, it mantles the late Eocene surface. Lithologically, the conglomerate is characterized by an abundance of red, purple, and gray aphanitic and porphyritic volcanic clasts, gray and light-green cobbles and boulders of dense quartzite, and fewer clasts of Wall Mountain Tuff. The volcanic clasts exhibit a wide range of decomposition, some being so fragile that they must have decomposed after deposition. In some areas volcanic clasts-other than those of the Wall Mountain Tuff-are absent because volcanic rocks were lacking in the source areas. Clasts of lower Paleozoic limestone and dolomite are less abundant. Precambrian detritus ranges in amount from sparse to dominant, depending on the local bedrock and on whether the site of deposition is a tributary or a mainstem drainage. Clasts of the Wall Mountain Tuff are generally present even where Precambrian detritus dominates, and, together with other Oligocene volcanic-rock detritus, serve to distinguish this unit from the prevolcanic Echo Park Alluvium. The typical geomorphic expression consists of rounded grass-covered ridges and slopes strewn with cobbles and boulders, of which the resistant quartzite clasts, where present, are especially noticeable. In and near the type locality, several feet of bentonitic strata at the top of the conglomerate is an important host rock for uranium deposits; uranium also occurs locally in the conglomerate. 
The stratigraphic position of the Tallahassee Creek Conglomerate between the Wall Mountain Tuff and the Thirtynine Mile Andesite shows that it is early Oligocene in age. The formation represents boulder alluvium deposited in paleovalleys incised into the late Eocene erosion surface. The valleys drained eastward from the ancestral Sawatch Range, picked up drainages flowing southeastward out of South Park, and flowed out onto the High Plains by draining southward through the Tallahassee Creek area and the High Park-Oil Creek area into the Canon City embayment (Scott, 1970 in an unpublished presidential address to the Colorado Sci. Soc., entitled "Geomorphic evolution of the southern Front Range, Colorado"; Chapin and others, 1970; Epis and Chapin, 1973). Ash flows of the Wall Mountain Tuff utilized these same valleys and left them partially filled with tuff. Erosion stripped most of the tuff from the interfluves and reduced the deposits within the valleys to discontinuous patches prior to the period of aggradation that formed the Tallahassee Creek Conglomerate. The Castle Rock Conglomerate in the Denver basin is not equivalent to the Tallahassee Creek Conglomerate because the former contains abundant clasts of the Thirtynine Mile Andesite and is therefore younger. The Thirtynine Mile Andesite disrupted the drainages in which the Tallahassee Creek Conglomerate was deposited and diverted them across the Front Range to the Castle Rock area.

\section{THIRTYNINE MILE ANDESITE}

This unit was referred to as the "Thirtynine Mile volcanic series" by Stark and others (1949, p. 101), and we (Epis and Chapin, 1968, p. 64) informally termed it the "lower andesite." We here name the formation the Thirtynine Mile Andesite and describe lower and upper members for the excellent exposures, which make up the type locality, from the southern base of Thirtynine Mile Mountain to its summit in T. 14 S., R. $73 \mathrm{~W}$., in the southeast quarter of the Guffey quadrangle. (fig. 1). There, the lower member is about 1,400 feet thick, and the upper member is about 1,200 feet thick; the tuff of Stirrup Ranch is absent. Cross (1894) recognized these andesitic rocks in the western part of the Pikes Peak quadrangle and separated them into a lower "basic breccia and agglomerate" and an upper "massive andesite," a subdivision which generally parallels our definition of the lower and upper members, respectively. In the type locality, the lower member overlies Precambrian rocks and some of the intermediate domes and flows of the Guffey volcanic center. Other domes intrude the lower member, and at Cover Mountain, about 6 miles to the southeast, a large dome intrudes the upper member. Thus, volcanism at the Guffey center had a long and complex history; eventually, the domes and domal flows were almost entirely buried by the Thirtynine Mile Andesite. The Wall Mountain Tuff is missing in the type locality of the Thirtynine Mile 
Andesite but is present as discontinuous patches beneath the lower member in the Chumway Park area, about 2 miles to the southwest. Because of its occurrence as the flanks of a large composite volcano, the upper member has not been observed in direct contact with the younger formations of the field, and its stratigraphic position must be inferred on the basis of radiometric dates and geomorphic considerations.

\section{LOWER MEMBER}

The lower member of the Thirtynine Mile Andesite is mostly chaotically stratified unsorted well-indurated purple, gray, brown, and black breccias of diverse origin and mode of emplacement that weather into rolling hills and slopes with poor soils and sparse vegetation. Deuteric alteration has imparted a purplish cast to most outcrops. The breccias vary vertically and laterally to form a complex sheet. The bulk of the lower member is made up of laharic breccias-both pyroclastic (erupted as mudflows) and epiclastic-that spread laterally from numerous small randomly scattered vents (Chapin and Wyckoff, 1969). Flow breccias comprise only about 10 percent of the unit; bedded tephra, cinder cones, and other products of violent pyroclastic eruptions are notably scarce, as are unbrecciated lava flows. Vents are marked by small breccia cones, as much as 500 feet high and 0.5 mile in diameter, and (or) breccia dikes, and short autobrecciated flows. Individual lahars are generally 3-20 feet thick, have highly irregular tops and bottoms, and can be followed for only short distances. Dark-colored nonvesicular pyroxene andesite is the most abundant petrographic type, but hornblende- and biotite-bearing andesite is also present in some breccias. Rocks of the lower member exhibit a wide range in chemical composition (table 1); many of the autoclastic breccias in or near vents are buff to red felsites of silicic composition.

The lower member averages 500 feet in thickness and initially covered about 1,000 square miles, extending from the eastern half of the Antero Reservoir quadrangle to the base of Mount Pisgah, near Cripple Creek, and from Hartsel southward to the Arkansas River valley. Interbedded fluvial gravels and tuffs are scarce, indicating that drainage within the volcanic field was largely disrupted by emplacement of the lower member of the Thirtynine Mile Andesite. It buried all but the highest features of the preexisting landscape which is underlain mainly by Precambrian rocks and the Wall Mountain Tuff; it also dammed streams and created large lakes along the north side of the breccia sheet, such as those in which the Antero and Balfour Formations, and Florissant Lake Beds accumulated. The Balfour (Johnson, 1937; Stark and others, 1949) and Florissant (Cross, 1894) deposits apparently are fluvial and lacustrine time equivalents of the breccia sheet; some of the Antero (Johnson, 1937; Stark and others, 1949) is younger, having been derived by reworking of white biotite-rich non- 
welded Badger Creek Tuff, which is partly younger than the lower member of the Thirtynine Mile Andesite in the western and southern parts of the field.

\section{TUFF OF STIRRUP RANCH}

The tuff of Stirrup Ranch occurs as thin discontinuous bouldery erosional remnants within the basal 200 feet of the lower member of the Thirtynine Mile Andesite. We (Epis and Chapin, 1968, p. 65) previously referred to it as ash flow 3 but here give it the informal name tuff of Stirrup Ranch after good exposures west of the Antelope Mountains and north of Waugh Mountain in the northwest quarter of the Black Mountain quadrangle, secs. 14, 23, and 26, T. 51 N., R. 12 E. Good exposures also occur at the east end of Waugh Mountain, in sec. 5, T. 17 S., R. $73 \mathrm{~W}$., and sec. 32 , T. 16 S., R. $73 \mathrm{~W}$., where its stratigraphic positions are especially clear. Near the junction of North and Middle Tallahassee Creeks and along North Tallahassee Creek in sec. 10, T. 17 S., R. 73 W., the tuff of Stirrup Ranch rests directly on the Tallahassee Creek Conglomerate. Between these two localities, and farther to the northwest, the tuff occurs as much as 200 feet high in the lower member of the Thirtynine Mile Andesite. Apparently, ridges of the Tallahassee Creek Conglomerate were exposed above the basal mudflows of the Thirtynine Mile Andesite at the time the tuff of Stirrup Ranch was emplaced.

The tuff of Stirrup Ranch is very similar to the Wall Mountain Tuff in color, texture, mineralogy, weathering characteristics, and chemical composition (table 1 ). The $2 \mathrm{~V}$ values of sanidine (range $29^{\circ}-57^{\circ}$, median $34^{\circ}$ ) are about midway between the extremes of the four ash flows making up the Wall Mountain Tuff. Thus, the two units can be distinguished only on the basis of stratigraphic position. Outcrops of welded tuff that rest on andesitic breccias north and east of Antero Reservoir (sec. 32, T. 11 S., R. 76 W., and secs. 4, 9, 13, 14, and 24, T. 12 S., R. 24 W.) and were included in the Agate Creek Formation by De Voto $(1961)$ and Lozano $(1965,1967)$ are probably remnants of the tuff of Stirrup Ranch. The source of the tuff is unknown, but, presumably, the tuff represents a slightly later product of the same magma that gave rise to the Wall Mountain Tuff.

\section{UPPER MEMBER}

The upper member of the Thirtynine Mile Andesite occurs in the central part of the field, where it caps the upper parts of Thirtynine Mile, Saddle, Castle, McIntyre, Witcher, and Black Mountains, which surround the Guffey volcanic center. It consists of distinctly stratified andesite flows, lesser amounts of interbedded breccias, and minor amounts of ash-fall tuffs and represents the remnant flanks of a large composite volcano centered between Guffey and Chumway Park, which we previously termed the "Guffey volcano" (Epis and Chapin, 1968, p. 
66). The contact between the upper and lower members of the Thirtynine Mile Andesite is locally gradational and is placed at the change in slope from rounded topography established on breccias to steep ledgelike topography developed on interbedded flows and lesser breccias. Rocks of the upper member vary widely in chemical composition (table 1), as do those of the lower member. Dark basaltic andesites containing abundant pyroxene phenocrysts as much as $1 / 4$ inch in long dimension are the most abundant rock types. Other flows, however, contain biotite or hornblende phenocrysts and are more silicic in composition.

Lavas of the upper member spread several miles southeastward from the Guffey volcano and form Cap Rock Ridge in the central Cover Mountain quadrangle; they also spread northeastward over the Florissant Lake Beds in the east-central part of the Florissant quadrangle. Apparently, there were no younger volcanic units of the field of sufficient volume and thickness to overlap the upper member of the Thirtynine Mile Andesite, for we did not find any units resting upon it.

Geochron Laboratories, Inc., determined a whole-rock K-Ar age of $34.1 \pm 1.1 \mathrm{~m} . \mathrm{y}$. for a sample of the upper member from near the top of Thirtynine Mile Mountain. This determination, along with others we have obtained from older formations-from the Florissant Lake Beds $(34.1 \pm 0.8$ m.y.), and from the Antero Formation (33.7 \pm 0.8 m.y., 33:6 \pm 0.7 m.y.) -indicates that the Thirtynine Mile Andesite is early Oligocene in age. (See fig. 2.)

\section{BADGER CREEK TUFF}

Epis and Chapin (1968, p. 69-70) referred to this unit informally as the tuff of Badger Creek and considered it to be a basal member of the Antero Formation of Johnson (1937). Recent detailed mapping by Lowell $(1969,1971)$ and reexamination by us indicate that the tuff is both younger and older than the Antero, and locally the Antero was eroded before the upper part of the Badger Creek was deposited. We here name the unit the Badger Creek Tuff for excellent exposures at the type locality in the $\mathrm{NE}^{1 / 4}$ sec. $12, \mathrm{~T} .50 \mathrm{~N}$., R. $10 \mathrm{E}$., in the valley of East Badger Creek in the Cameron Mountain quadrangle, 11 miles northeast of Salida (fig. 1). The Badger Creek Tuff is exposed for 10 miles west of the type locality in the central part of the Cameron Mountain quadrangle, where it partially fills the east-trending prevolcanic paleovalley between Browns Canyon and Waugh Mountain. At the type locality Lowell (1969) measured 313 feet of the Badger Creek Tuff. It rests on either Precambrian crystalline rocks, the Wall Mountain Tuff, Tallahassee Creek Conglomerate, or the Antero Formation and is overlain by a local latite flow which, in turn, is overlain by the Gribbles Park Tuff. The Badger Creek Tuff is also well exposed in the paleovalley at Trout Creek and southward along the southwestern 
margin of the Antero Reservoir quadrangle, where it locally is as much as 800 feet thick and was referred to by De Voto (1971, p. 25-26) as the andesitic tuff of Castle Rock Gulch. G. R. Scott (oral commun., 1970) mapped outcrops of a similar tuff east of Howard in the Arkansas River valley. Two outcrops of the Badger Creek Tuff have also been observed east of Waugh Mountain; one of these caps the high butte one-half mile south of the Thorn Ranch headquarters, in secs. 22 and 23, T 17 S., R. $73 \mathrm{~W}$.

The Badger Creek Tuff is a compound-cooling unit consisting of a series of petrographically similar ash flows, at least six of which can be discerned at the type locality. Multiple thin, densely welded dark-gray to black vitrophyre and piperno zones are present locally, but the tuff is characterized mainly by moderate welding and compaction. Eutaxitic fabric is well developed and causes the formation to split into thin slabs and plates upon weathering. The tuff generally crops out in rounded hills or modest slopes but, in places, forms clifflike exposures.

The Badger Creek Tuff weathers yellowish gray to buff and tends to be light gray to light reddish brown when fresh. Hand specimens have a "salt-and-pepper" appearance because of the abundance of black biotite and hornblende crystals mixed with light-pink and white pumice lapilli. Crystal fragments make up about 30-35 percent of the rock, and strongly zoned plagioclase crystals (andesine) comprise 70-80 percent of the crystals. Biotite and opaque oxides are second in abundance, accounting for $15-20$ percent of the crystals. Sanidine and hornblende usually make up 2-5 percent each; sphene is a conspicuous accessory. Chemically, the tuff is quartz latite (table 1). Gray and brown accessory lithic lapilli are moderately abundant. The ash flows in the Badger Creek Tuff are remarkably similar in both mineralogical and chemical composition (table 1) to unwelded ash-flow tuffs in the Antero Formation; they most likely were erupted from the same source and locally may be contemporaneous.

Because of its stratigraphic position nearly equivalent to the Antero Formation and below the Gribbles Park Tuff, the Badger Creek Tuff must be Oligocene in age. Graebner (1967) determined a reverse remanent magnetic polarity for the unit. The source of this tuff is unknown, but, like the Wall Mountain Tuff, it must have originated west of its present outcrop area.

\section{EAST GULCH TUFF}

Previously, we (Epis and Chapin, 1968, p. 71) termed this unit "ash flow 5"; we now name it the East Gulch Tuff for good outcrops at the type locality in East Gulch, in secs. 2, 3, and 11, T. 49 N., R. 12 E., in the south-central part of the Black Mountain quadrangle (fig. 1). In this type locality the tuff is 70 feet thick, but elsewhere its average is about 50 feet. The tuff fills a small paleovalley near Waugh Mountain and is 
more sheetlike to the south and southeast. It has been mapped by Scott and Taylor (1974) near Howard and Hillside. Generally, the East Gulch Tuff rests on the Antero Formation and is separated by an erosional interval from the overlying Thorn Ranch Tuff; locally, it lies on older volcanic rocks or on Precambrian basement and is overlain by volcanic units younger than the Thorn Ranch Tuff.

The East Gulch Tuff weathers light gray and, locally, light brown. It is a simple-cooling unit with well-developed zonation and a conspicuous eutaxitic fabric. A black vitrophyre zone as much as 15 feet thick is common in the lower third of the tuff; the vitrophyre zone grades upward into a piperno zone in which lenses of black glass, formed by collapsed pumice lapilli, are interspersed in a gray vitroclastic matrix. Moderately welded zones contain abundant, partly collapsed black, gray, and cream pumice in a light-brown matrix. Locally, the unit is only slightly welded throughout. The tuff is rhyolitic, both mineralogically and chemically (table 1), containing sanidine, plagioclase, quartz, and biotite as the important phenocrystic minerals. The $2 \mathrm{~V}$ values of sanidine range from $16^{\circ}$ to $36^{\circ}$ with a median of $27^{\circ}$ (Chapin, 1965). Lithic fragments of both Precambrian rocks and accessory volcanic rocks are abundant.

The stratigraphic position of the East Gulch Tuff, above the Antero Formation and below the Thorn Ranch Tuff, indicates an Oligocene age. Studies of remanent magnetism by Graebner (1967) indicate a reverse polarity. The source of the unit is unknown but is west of its present outcrops.

\section{THORN RANCH TUFF}

In the past we (Epis and Chapin, 1968, p. 72) have called this unit ash flow 6; we here name it the Thorn Ranch Tuff for good exposures at its type locality along the mesa near Thorn Ranch, at $\mathrm{S} 1 / 2$ sec. 23 and $\mathrm{N} 1 / 2$ sec. 26, T. 17 S., R. $73 \mathrm{~W}$., in the southeast quarter of the Black Mountain quadrangle (fig. 1). The tuff rests on the Antero Formation and is overlain at the southeast end of the mesa by the Gribbles Park Tuff. The East Gulch Tuff is not present at the Thorn Ranch type locality but is well exposed beneath the Thorn Ranch Tuff on the mesa between Middle and South Tallahassee Creeks in $\mathrm{S} 1 / 2$ sec. 28 and N1/2 sec. 33, T. $17 \mathrm{~S}$., R. $73 \mathrm{~W}$., about 2 miles southwest of the type locality.

The Thorn Ranch Tuff forms prominent reddish-brown caprocks with well-developed columnar jointing on the mesas near the confluence of the three forks of Tallahassee Creek. The moderately welded cliff-forming zone is $40-80$ feet thick, and, where not stripped by erosion, it grades imperceptibly upward into a pinkish-white unwelded zone. Chapin (1965, p. 160) measured 245 feet of Thorn Ranch Tuff at the north end of Echo Park, but the unit generally is much thinner because the soft, upper zone has been eroded. The tuff occurs from the 
Badger Creek valley, west of Black Mountain, southeastward through Waugh Mountain and the Tallahassee Creek area. Scott and Taylor (1974) mapped the unit as far south as Goat Creek near Hillside in the northern Wet Mountain valley.

The Thorn Ranch Tuff is a simple-cooling unit of nonwelded to moderately welded tuff that weathers pinkish-white to reddish brown, depending on the degree of welding. It contains pink and white pumice, Precambrian lithic fragments, and brown aphanitic accessory lithic fragments. The tuff is rhyolitic, both mineralogically and chemically (table 1), and contains sanidine, plagioclase, quartz, and biotite as the important phenocrysts. The $2 \mathrm{~V}$ values of sanidine range from $18^{\circ}$ to $42^{\circ}$ with a median of $28^{\circ}$ (Chapin, 1965). Devitrification of the glassy constituents is complete, and vaporphase alteration of pumice is extensive, especially in the moderately welded zone, where spherulitic replacement of pumice simulates small "birds' nests."

The stratigraphic position of the Thorn Ranch Tuff, above the East Gulch Tuff and below the Gribbles Park Tuff, indicates an Oligocene age. Like the East Gulch Tuff, it exhibits reverse polarity (Graebner, 1967). Its source is unknown.

\section{GRIBBLES PARK TUFF}

In earlier works we (Epis and Chapin, 1968, p. 72) referred to this unit as ash flow 7 and here name it the Gribbles Park Tuff for exposures along the north and south sides of Gribbles Park, in the northeast quarter of the Cameron Mountain quadrangle. The tuff is about 300 feet thick at its type locality (fig. 1), where it caps mesas along the north side of Gribbles Park, in the $\mathrm{W}^{1 / 2}$ sec. 16 and the $\mathrm{E}^{1 / 2}$ sec. 17, T. 51 N., R. 11 E., but on Two Creek in the $\mathrm{E}^{1 / 2} \mathrm{sec} .5$, T. 50 N., R. 11 E., about 2 miles south of Gribbles Park, it is 590 feet thick in the paleovalley that extends eastward from Browns Canyon to Waugh Mountain. Along the north slope of Two Creek, the Gribbles Park Tuff contains three distinct members which form a compound-cooling unit. In ascending order, these members weather brown, gray, and red and have thicknesses of 240,230 , and 110 feet, respectively. Between the brown and gray members is an orange unwelded tuff, about 10 feet thick, which may be an unwelded top of the brown member, an unwelded bottom of the gray member, or a separate ash flow. The members form benchlike topographic features, but talus obscures the contacts. The Gribbles Park Tuff overlies the Antero Formation and, locally, the Thorn Ranch Tuff along the north side of Gribbles Park, but the top of the Gribbles Park has been eroded. In the paleovalley south of Gribbles Park, it rests on prevolcanic rocks, the Antero Formation, and a local latite flow which overlies both the Antero Formation and the Badger Creek Tuff; latitic flows and flow breccias from the Waugh Mountain center overlie the Gribbles Park Tuff at this locality. 
Southeast of Waugh Mountain, the Gribbles Park Tuff rests on the Thorn Ranch Tuff and is overlain by the conglomerate of Fear Creek or the andesite of Waugh Mountain (fig. 2). Chapin (1965) measured 290 feet of the Gribbles Park Tuff with an eroded top at the north end of Echo Park; there, the unit forms impressive cliffs of massive purplishgray to brown tuff without apparent cooling breaks.

The Gribbles Park Tuff is an important stratigraphic marker in the Thirtynine Mile volcanic pile because of its distinctive lithology and widespread occurrence. The unit extends from southern South Park at Wagontongue Creek southward and southeastward beneath Waugh Mountain to the plains near Canon City and into the Wet Mountain valley on the De Weese Plateau and at Goat Creek (Scott and Taylor, 1974). Before its disruption by late Cenozoic block faulting and erosion, the tuff must have covered most of the area between these localities (approximately $1,200 \mathrm{sq} \mathrm{mi}$ ) and thus aided preservation of the prevolcanic erosion surface beneath it. South of the Arkansas River many isolated patches of the tuff rest on this rather smooth surface that is carved on Precambrian crystalline rock.

Although the three members of the Gribbles Park Tuff differ in color, they are similar in composition and are characterized by abundant chatoyant-blue sanidine crystals, bronze-colored biotite, and darkbrown and gray accessory lithic fragments. Pumice lapilli are abundant in the red member and in the orange tuff and have diameters as large as 10 inches; pumice lapilli are less conspicuous in the brown and gray members which form massive outcrops with poorly developed eutaxitic fabric. The orange tuff is unwelded, but the other units are moderately to densely welded; black vitrophyre zones occur locally at the base of the lower member. Phenocrysts in the tuff vary mineralogically, but chemically the rock is a rhyolite (table 1). Phenocrysts constitute 15-30 percent of the rock; of these, sanidine makes up 40-70 percent, plagioclase (andesine) 10-25 percent, and biotite and opaque oxides 520 percent (Lowell, 1969). Pyroxene, hornblende, and sphene are commonly present in trace amounts. The $2 \mathrm{~V}$ value of sanidine ranges from $26^{\circ}$ to $38^{\circ}$ with a median of $32^{\circ}$ (Chapin, 1965); Lowell (1969) found that the median $2 \mathrm{~V}$ value of sanidine was virtually the same in all three members.

Epis and Chapin (1968, p. 72) reported a K-Ar age of $34.8 \pm 1.4$ m.y. as determined by Geochron Laboratories, Inc., on a sanidine separate from the Gribbles Park Tuff. Recent K-Ar age determinations by J. D. Obradovich of $28.6 \pm 0.6$ and $29.5 \pm 0.7 \mathrm{~m} . \mathrm{y}$. on two sanidine separates indicate that the earlier determination is too old probably because of contamination. Accordingly, we assign a late Oligocene age to the formation. A normal remanent magnetic polarity was determined by Graebner (1967). The source of the Gribbles Park Tuff is unknown, but, 
like the earlier ash flows of the Thirtynine Mile volcanic field, it is west of the known outcrop area of the tuff.

\section{CONGLOMERATE OF FEAR CREEK}

This unit was referred to in earlier reports (Epis and Chapin, 1968, p. 74) as the upper volcanic conglomerate. It is here given the informal name conglomerate of Fear Creek for extensive exposures along the flat tablelands between Fear Creek and East Gulch, in the $\mathrm{S} 1 / 2$ sec. 30 and sec. 31 , T. 17 S., R. 73 W., and secs. 4, 5, 6, 8, and 9, T. 18 S., R. 72 W., in the southeast quarter of the Black Mountain quadrangle. The unit is now exposed over an area of less than 10 square miles and is, therefore, only accorded an informal designation. It fills a southeast-trending paleovalley 1-2 miles wide and as much as 350 feet deep incised into the Gribbles Park Tuff and is overlain by the andesite of Waugh Mountain. The unit averages about 200 feet in thickness and extends eastward as far as Table Mountain in the southeast corner of the Black Mountain quadrangle. It was undoubtedly much more extensive originally, but deep dissection of the area to the south and east by the Arkansas River and its tributaries has removed much of the unit.

The conglomerate of Fear Creek consists mainly of gray, wellstratified, poorly cemented pebble to boulder conglomerate predominantly of andesitic composition. Two channel-shaped cross sections of the unit are spectacularly exposed at the north end of Echo Park, in secs. 8,9 , and 10 , T. 18 S., R. 73 W., along the south edge of the Black Mountain quadrangle and the north edge of the Cotopaxi quadrangle. In the western channel, a conspicuous white tuff occurs about 200 feet above the base of the channel and is visible from U.S. Highway 50 in the bottom of the Arkansas River canyon. The tuff is made up of several feet of well-stratified waterlaid tuffs overlain by about 30 feet of massive nonwelded ash-flow tuff which contains abundant black biotite. J. D. Obradovich determined the following K-Ar ages from mineral separates from the ash-flow tuff: Hornblende, $28.8 \pm 0.9$; biotite, $27.7 \pm 0.6$; sanidine, $26.8 \pm 0.6$ and $27.8 \pm 0.6$ m.y. About 100 feet of andesitic conglomerate overlies the dated tuff and is overlain, in turn, by the andesite of Waugh Mountain. In the eastern channel, about 200 feet of massive gray andesitic laharic breccias underlies similar white tuffs. Coarse conglomerate also occurs there between the white tuffs and the overlying andesite of Waugh Mountain. On the tablelands to the northwest, the conglomerate of Fear Creek forms rounded boulder-strewn ridges where it is not capped by the andesite of Waugh Mountain.

The K-Ar age determinations on the interbedded white tuff indicate a late Oligocene age for the conglomerate of Fear Creek and negate any possible correlation with lithologically similar conglomerates of the 
Trump Conglomerate of Johnson (1937) in southwestern South Park. The source of the interbedded tuffs and mudflow breccias was probably the Waugh Mountain volcanic center about 6 miles upstream (northwest). At this center, intermediate to silicic domes and flows intrude and overlie the Gribbles Park Tuff and are overlain by the andesite of Waugh Mountain. The great abundance of andesitic detritus in the conglomerate of Fear Creek suggests that some of the units we have grouped with the andesite of Waugh Mountain may be late Oligocene in age or coeval with the silicic domes and flows of the Waugh Mountain center.

\section{ANDESITE OF WAUGH MOUNTAIN}

Formerly, we (Epis and Chapin, 1968, p. 75) referred to this unit as the upper andesite, but here we give it the informal name andesite of Waugh Mountain. Several areas of andesitic to basaltic rocks in the southern part of the field are included in the unit on the bases of similarities in lithology and stratigraphic position. However, some of these outcrops are not physically continuous and may vary considerably in age. These rocks are the least studied volcanic units in the Thirtynine Mile field, and more fieldwork and petrographic work must be done before formal subdivisions can be made. The unit described here should be considered as a grouping of similar rocks, for the sake of convenience, until definitive work is accomplished.

The andesite of Waugh Mountain is named for extensive exposures on the largest mountain in the southern part of the field. The upper slopes of Waugh Mountain (T. 50 N., Rs. 11 and 12 E.), above about 10,200 feet in altitude on the east end, 10,600 feet on the north side, and 10,400 feet at the west end, are composed largely of andesitic to basaltic rocks which dip gently to the south and southeast and constitute the top of the volcanic pile. Their combined thickness exceeds 1,200 feet.

The andesite of Waugh Mountain consists mainly of a series of thin flows of andesite, basaltic andesite, and basalt with minor interbedded flow breccias, laharic breccias, and tuffs. The rocks are dark colored, generally purplish brown, greenish black or black, aphanitic to porphyritic-aphanitic, and exhibit local vesicular phases. Pyroxene and plagioclase are the most common phenocrysts, with or without minor olivine or hornblende. Thin dikes of similar compositions near the center of Waugh Mountain may have served as feeders for much of the formation, but it is equally likely that there are local sources elsewhere, particularly for the occurrences south of the Arkansas River.

Near the middle of Waugh Mountain, a volcanic center of intermediate to silicic domes and flows has been partially exhumed from beneath the andesites by the headwaters of North Waugh Creek on the north side of Waugh Mountain and those of Fernleaf Gulch south of Waugh Mountain. West of these domes, 400-800 feet of light-gray latitic 
flows and flow breccias separates the Gribbles Park Tuff from the overlying andesite of Waugh Mountain. East of the domes the latite flows are missing, and the andesite of Waugh Mountain rests directly on the Gribbles Park Tuff.

Southeast of Waugh Mountain, the mesas which rim the Arkansas River canyon on the north side are capped by 200-300 feet of dark olivine-bearing basaltic andesite flows (table 1, samples W170622 and W170645), which overlie the conglomerate of Fear Creek. The altitude of the base decreases from 9,300 feet on the west to 8,500 feet on the east. in a distance of about 7 miles. At the east end the flows overlap the eroded edge of the Gribbles Park Tuff and rest directly on Precambrian rocks. In a previous paper we (Epis and Chapin, 1968) correlated these flows with the andesites on Waugh Mountain, but they are not physically continuous, and we now doubt that correlation. Geochron Laboratories, Inc., determined a K-Ar age of $18.9 \pm 1.2 \mathrm{~m}$.y. for a wholerock sample collected from a basaltic andesite flow at the north end of Echo Park, but andesitic clasts similar to the andesites on Waugh Mountain are abundant in the conglomerate of Fear Creek beneath the interbedded ash-flow tuff which yielded ages between 26 and 28 m.y. Hence, at least some of the andesites on Waugh Mountain may be older than, or coeval with, the conglomerate of Fear Creek, and the basaltic andesite flows capping the mesas may represent younger fissure eruptions. Other isolated outcrops of andesitic to basaltic flows south and southwest of Waugh Mountain, such as those near Howard in the Arkansas River canyon (G. R. Scott, oral commun., 1971) and those near Oak Creek and Hillside at the north end of the Wet Mountain Valley (Scott and Taylor, 1974), are tentatively included in the andesite of Waugh Mountain on the basis of similar lithology and stratigraphic position; however, further dating may necessitate refinement of this grouping.

\section{REFERENCES CITED}

Buchanan, P. H., 1967, Volcanic geology of the Guffey area, Park County, Colorado: Colorado School Mines unpub. M.S. thesis, 95 p.

Burbank, W. S., Lovering, T. S., Goddard, E. M., and Eckel, E. B., 1935, Geologic map of Colorado: U.S. Geol. Survey, scale: 1:500,000 [reprinted 1959].

Chapin, C. E., 1965, Geologic and petrologic features of the Thirtynine Mile volcanic field, central Colorado-Pt. 1, General geology; Pt. 2, Correlation of ash-flow tuffs by the use of optic axial angles of alkali feldspar crystals: Colorado School Mines unpub. D. Sc. thesis, $176 \mathrm{p}$.

Chapin, C. E., and Epis, R. C., 1964, Some stratigraphic and structural features of the Thirtynine Mile volcanic field, central Colorado: Mtn. Geologist, v. 1, no. 3, p. 145160.

Chapin, C. E., Epis, R. C., and Lowell, G. R., 1970, Late Eocene paleovalleys and Oligocene volcanic rocks along the upper Arkansas valley segment of the Rio Grande rift zone in Colorado [abs.], in The Rio Grande Depression, New Mexico and Colorado: New Mexico Geol. Soc. 24th Ann. Mtg., Program, p. 6. 
Chapin, C. E., and Wyckoff, B. S., 1969, Formation of a sixty-cubic-mile andesitic breccia sheet in the Thirtynine Mile volcanic field of central Colorado, in Abstracts for 1968: Geol. Soc. America Spec. Paper 121, p. 52.

Cross, Whitman, 1894, Description of the Pikes Peak sheet, Colorado: U.S. Geol. Survey Geol. Atlas, Folio 7, 5 p.

De Voto, R. H., 1961, Geology of southwestern South Park, Park and Chaffee Counties, Colorado: Colorado School Mines unpub. D. Sc. thesis, 323 p.

1964, Stratigraphy and structure of Tertiary rocks in southwestern South Park: Mtn. Geologist, v. 1, no. 3, p. 117-126.

1971, Geologic history of South Park and geology of the Antero Reservoir quadrangle, Colorado: Colorado School Mines Quart., v. 66, no. 3, 90 p.

Dings, M. G., and Robinson, C. S., 1957, Geology and ore deposits of the Garfield quadrangle, Colorado: U.S. Geol. Survey Prof. Paper 289, 110 p.

DuHamel, J. E., 1968, Volcanic geology of the upper Cottonwood Creek area, Park and Fremont counties, Colorado: Colorado School Mines unpub. M.S. thesis, 120 p.

Epis, R. C., and Chapin, C. E., 1968, Geologic history of the Thirtynine Mile volcanic field, central Colorado, in Epis, R. C., ed., Cenozoic volcanism in the Southern Rocky Mountains: Colorado School Mines Quart., v. 63, no. 3, p. 51-85.

1973 , Geomorphic and tectonic implications of the post-Laramide late Eocene erosion surface in the Southern Rocky Mountains: Geol. Soc. America Abs. with Programs, v. 5, no. 6, p. 479.

Graebner, Peter, 1967, Remanent magnetism in major rock units of the Thirty nine Mile volcanic field, central Colorado; Colorado School Mines unpub. M.S. thesis, 165 p.

Graebner, Peter, and Epis, R. C., 1968, Remanent magnetism in major rock units of the Thirtynine Mile volcanic field, central Colorado [abs.], in Epis, R. C., ed., Cenozoic volcanism in the Southern Rocky Mountains: Colorado School Mines Quart., v. 63, no. 3 , p. $87-88$.

Harland, W. B., Smith, A. G., and Wilcock, Bruce, eds., 1964, The Phanerozoic time scale-A symposium dedicated to Professor Arthur Holmes: Geol. Soc. London Quart. Jour. Supp., v. 120 s, 458 p.

Izett, G. A., Scott, G. R., and Obradovich, J. D., 1969, Oligocene rhyolite in the Denver basin, Colorado, in Geological Survey research 1969: U.S. Geol. Survey Prof. Paper 650-B, p. B12-B14.

Johnson, J. H., 1937, The Tertiary deposits of South Park, Colorado, with a description of the Oligocene algal limestone [abs. of thesis]: Colorado Univ. Studies, v. 25, no. 1, p. 77.

Johnson, R. B., and Wood, G. H., Jr., 1956, Stratigraphy of Upper Cretaceous and Tertiary rocks of Raton basin, Colorado and New Mexico: Am. Assoc. Petroleum Geologists Bull., v. 40, no. 4, p. 707-721.

Lindgren, Waldemar, and Ransome, F. L., 1906, Geology and gold deposits of the Cripple Creek district, Colorado: U.S. Geol. Survey Prof. Paper 54, 516 p.

Lipman, P. W., Mutschler, F. E., Bryant, Bruce, and Steven, T. A., 1969, Similarity of Cenozoic igneous activity in the San Juan and Elk Mountains, Colorado, and its regional significance, in Geological Survey research 1969: U.S. Geol. Survey Prof. Paper 650-D, p. D33-D42.

Lowell, G. R., 1969, Geologic relationships of the Salida area to the Thirtynine Mile volcanic field of central Colorado: New Mexico Inst. Mining and Technology unpub. D. Sc. thesis, $113 \mathrm{p}$.

1971, Cenozoic geology of the Arkansas Hills region of the southern Mosquito Range, central Colorado, in San Luis Basin, Colorado: New Mexico Geol. Soc. Guidebook, 22d Field Conf., 1971, p. 209-217.

Lowell, G. R., and Chapin, C. E., 1972, Primary compaction and flow foliation in ash-flow tuffs of the Gribbles Run paleovalley, central Colorado: Geol. Soc. America Abs. with Programs, v. 4, no. 7, p. 725-726. 
Lozano, Efraim, 1965, Geology of the southwestern Garo area, South Park, Park County, Colorado: Colorado School Mines unpub. M.S. thesis, $115 \mathrm{p}$.

1967, Stratigraphy and structure of Tertiary rocks in central South Park, Park County, Colorado: Mtn. Geologist, v. 4, no. 4, p. 119-126.

Morris, G. R., 1969, Geology of the Dicks Peak area, Park County, Colorado: Colorado School Mines unpub. M.S. thesis, $69 \mathrm{p}$.

Niesen, P. L., 1969, Stratigraphic relationships of the Florissant Lake Beds to the Thirtynine Mile volcanic field of central Colorado: New Mexico Inst. Mining and Technology unpub. M.S. thesis, 65 p.

Sawatzky, D. L., 1964, Structural geology of southeastern South Park, Park County, Colorado: Mtn. Geologist, v. 1, no. 3, p. 133-139.

1967, Tectonic style along the Elkhorn thrust, eastern South Park and western Front Range, Park County, Colorado: Colorado School Mines unpub. D. Sc. thesis, $206 \mathrm{p}$.

Scott, G. R., and Taylor, R. B., 1974, Post-Paleocene Tertiary rocks and Quaternary volcanic ash of the Wet Mountain Valley, Colorado: U.S. Geol. Survey Prof. Paper 868 (in press).

Stark, J. T., Johnson, J. H., Behre, C. H., Jr., Powers, W. E., Howland, A. L., Gould, D. B., 1949, Geology and origin of South Park, Colorado: Geol. Soc. America Mem. 33, $188 \mathrm{p}$.

Tobey, E. F., 1969, Geologic and petrologic relationships between the Thirtynine Mile volcanic field and the Cripple Creek volcanic center: New Mexico Inst. Mining and Technology unpub. M.S. thesis, $61 \mathrm{p}$.

Van Alstine, R. E., 1969, Geology and mineral deposits of the Poncha Springs NE quadrangle, Chaffee County, Colorado: U.S. Geol. Survey Prof. Paper 626, 52 p.

Welsh, Fred, Jr., 1969, The geology of the Castle Rock area, Douglas County, Colorado: Colorado School Mines unpub. M.S. thesis, $93 \mathrm{p}$.

Wyckoff, B. S., 1969, Geology of the east side of the Guffey volcanic center (Oligocene), Park County, Colorado: New Mexico Inst. Mining and Technology unpub. M.S. thesis, $64 \mathrm{p}$. 



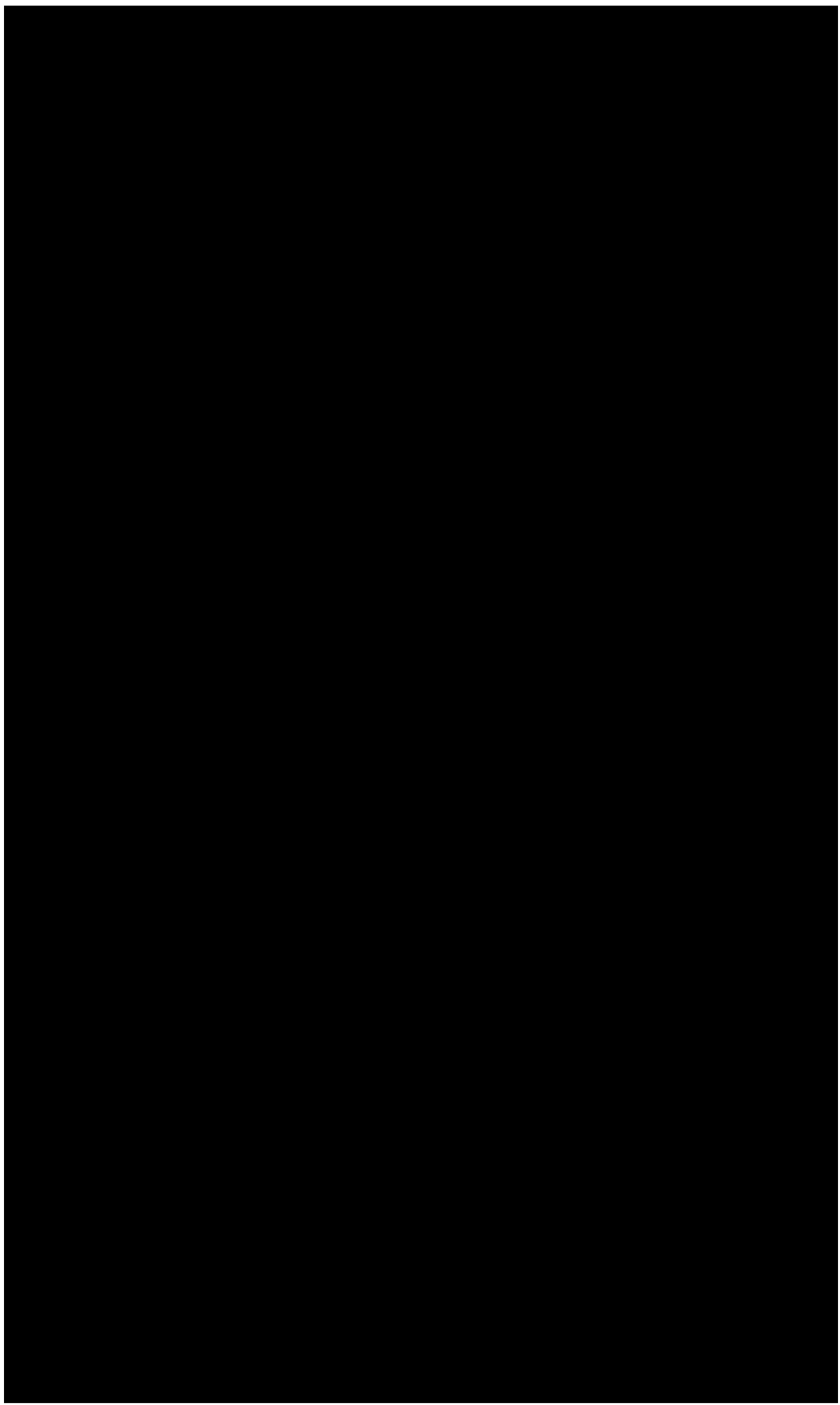




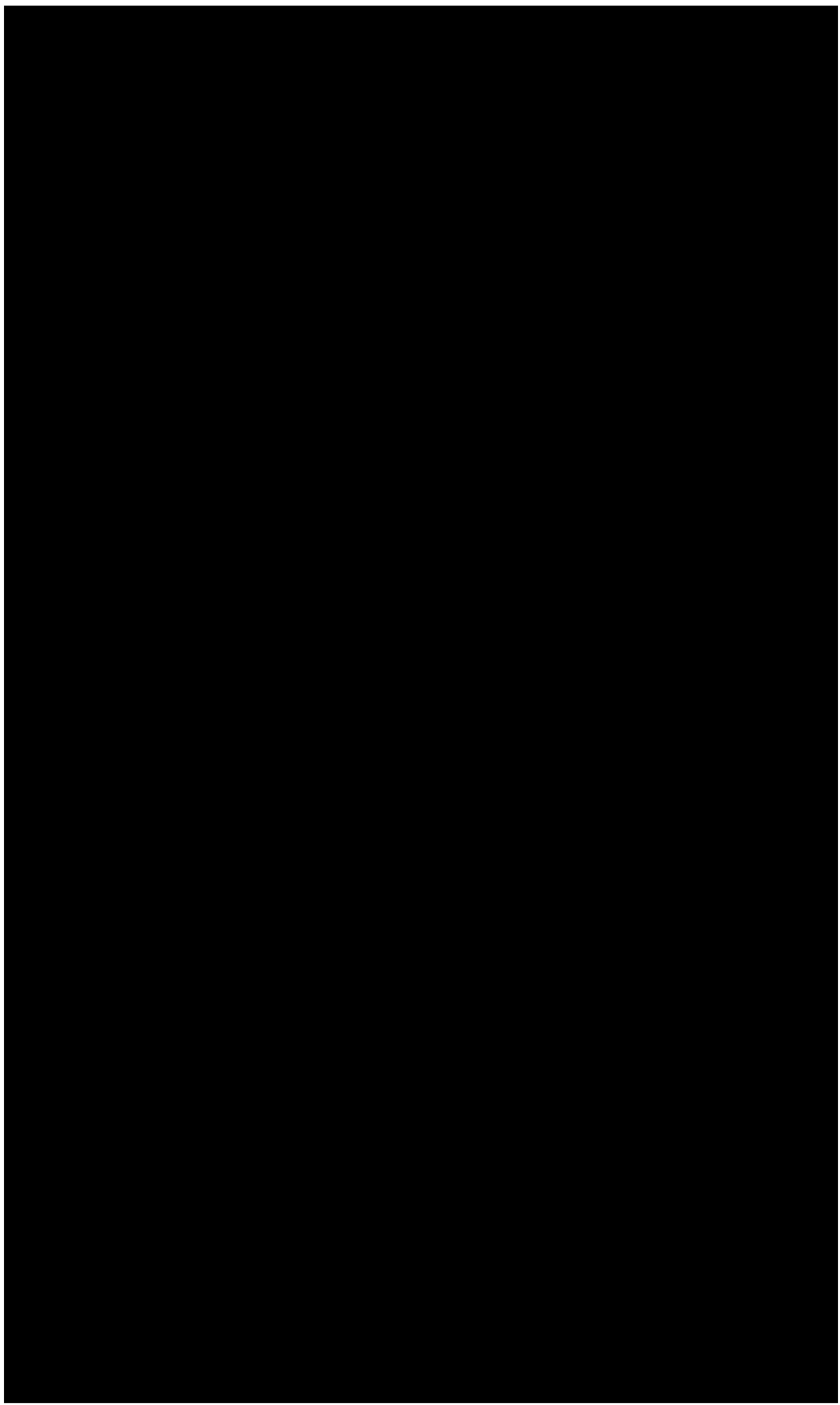

